\title{
Less invasive surgery of the proximal aorta
}

\author{
P Risteski , N Monsefi, T Josic, E Srndic, P llioska, A Moritz, A Zierer \\ From 23rd World Congress of the World Society of Cardio-Thoracic Surgeons \\ Split, Croatia. 12-15 September 2013
}

\section{Background}

Partial upper sternotomy (PUS) is established less invasive approach for single and double valve surgery. Reports of aortic surgery performed through PUS are rare.

\section{Methods}

The records of 52 patients undergoing primary elective surgery on the proximal aorta through PUS between 2005 and 2011 were reviewed. Patients mean age was 57 years, $35 \%$ were in NYHA Class III or IV, $59 \%$ had recent cardiac decompensation, and $17 \%$ had pulmonary hypertension. The PUS was taken down to the 4th left intercostal space in 44 patients $(85 \%)$.

\section{Results}

No conversion to full sternotomy was necessary. The aortic cross-clamp, cardiopulmonary bypass and operative times averaged $136 \pm 20 \mathrm{~min} ., 186 \pm 36 \mathrm{~min}$. and $327 \pm 83$ min., respectively. In eight patients, the right axillary artery was cannulated for establishing cardiopulmonary bypass; the others were cannulated centrally. All patients except one received a procedure on the ascending aorta, either replacement in $30(58 \%)$ or reduction aortoplasty in 21 (40\%). Aortic root replacement was additionally performed in 31 patients (60\%), including David in 20 (38\%) and Ross procedure in $6(11.5 \%)$. The aortic arch was replaced either partially in $5(10 \%)$ or totally in $3(6 \%)$ patients, in moderate hypothermia employing antegrade cerebral perfusion. Additional procedures, included mitral valve repair in $15(29 \%)$ patients and coronary grafting. Ventilation time, intensive care unit and hospital stay averaged $17 \pm$ 12 hours, $2 \pm 1$, and $11 \pm 9$ days. Chest drainage was 470 $\pm 380 \mathrm{ml} / 24$ hours. Permanent neurologic deficit did not occur. Wound dehiscence was observed in a single patient (2\%). Thirty-day and hospital mortality were not observed.

\footnotetext{
* Correspondence: petarristeski@me.com

Department of Thoracic and Cardiovascular Surgery, Johann Wolfgang
} Goethe University, Frankfurt am Main, Germany

\section{Conclusions}

Less invasive surgery on the aortic root, ascending aorta and aortic arch can be performed safely and reproducibly. Potential benefits include a minimized risk of wound dehiscence and reduced postoperative bleeding. The PUS does not compromise the quality of the operation.

Published: 11 September 2013

doi:10.1186/1749-8090-8-S1-036

Cite this article as: Risteski et al:: Less invasive surgery of the proximal

aorta. Journal of Cardiothoracic Surgery 2013 8(Suppl 1):036.
Submit your next manuscript to BioMed Central and take full advantage of:

- Convenient online submission

- Thorough peer review

- No space constraints or color figure charges

- Immediate publication on acceptance

- Inclusion in PubMed, CAS, Scopus and Google Scholar

- Research which is freely available for redistribution

\section{() Biomed Central}

C Biomed Central

(c) 2013 Risteski et al; licensee BioMed Central Ltd. This is an Open Access article distributed under the terms of the Creative Commons Attribution License (http://creativecommons.org/licenses/by/2.0), which permits unrestricted use, distribution, and reproduction in any medium, provided the original work is properly cited. 